\title{
PEMANFAATAN CAIR TEMPURUNG KELAPA DAN PENGARUHNYA TERHADAP ORGANOLEPTIK DAN KIMIAWI DAGING SAPI
}

\section{UTILIZATION COCONUT SHELL LIQUID AND ITS EFFECTS ON ORGANOLEPTIC AND CHEMICAL BEEF}

\author{
Y. Tamu Ina a dan I. Patu Sirappa
}

1Program Studi Peternakan, Fakultas Sains dan Teknologi, Universitas Kristen Wira Wacana Sumba Jl. R. Suprapto No. 35, Waingapu, Prailiu, Kabupaten Sumba Timur, NTT

aKorespondensi: Y. Tamu Ina, E-mail: yessytamuina@unkriswina.ac.id

(Diterima oleh Dewan Redaksi: 05-03-2021)

(Dipublikasikan oleh Dewan Redaksi: 30-04-2021)

\begin{abstract}
This study aims to obtain the best liquid smoke concentration as an ingredient in beef jerky by analyzing phenol content, protein content, benzo (a) pirene, benzo (a) anthrax and organoleptics in beef jerky. This study used a completely randomized design, namely soaking meat with different concentrations of liquid smoke. The use of coconut shell liquid smoke has 3 levels of fumigation concentration, namely P1 $=3 \%, \mathrm{P} 2=6 \%$, and P3 $=9 \%$. The need for soaking meat using liquid smoke is 15 samples. The variables measured were phenol content, protein content, benzo (a) pirene, benzo (a) anthracene, and organoleptic levels including color, taste, texture and preferences. First, the parameter test is tested for normality using the Shapiro-Wilk test. If the data distribution is normal, analyzed by ANOVA at the 5\% level, if there is an effect, then continue with the Duncan Dual Region test. Benzo (a) pyrene and benzo (a) levels were tested descriptively and organoleptic properties (color, taste, texture and level of preference) were tested using the Kruskal-Walis non-parametric test and continued, the Man Whitney test. The results of this study indicate that different concentrations of liquid smoke can have a significant effect $(\mathrm{P}<0.05)$ on protein, phenol and organoleptic levels. The highest concentration of liquid smoke can increase phenol levels, organoleptic but can reduce protein levels. While the levels of benzo (a) pyrene in all treatments were $<0.51 \mathrm{mg} / \mathrm{kg}$ and the levels of benzo (a) anthracene in all treatments were $<9.08$ and in health, the utilization of liquid smoke up to $9 \%$ was still safe for consumption.
\end{abstract}

Key words: Meat, liquid smoke concentration., Jerky, chemical jerky, organoleptic.

\begin{abstract}
ABSTRAK
Penelitian ini bertujuan untuk mendapatkan konsentasi asap cair terbaik sebagai bahan pembuat dendeng sapi dengan menganalisis kadar fenol, kadar protein, Benzo (a) pirene, Benzo (a) anttracena dan organoleptik pada dendeng sapi. Penelitian ini menggunakan menggunakan Rancangan Acak Lengkap yaitu perendaman daging dengan konsentrasi asap cair yang berbeda. Penggunaan asap cair tempurung kelapa mempunyai 3 taraf konsentrasi pengasapan yaitu P1=3\%, P2=6\%, dan P3=9\%. Kebutuhan untuk perendaman daging dengan menggunakan asap cair adalah 15 sampel. Variabel yang diukur adalah kadar fenol, kadar protein, kadar benzo (a) pirene, kadar benzo (a) antracena, dan organoleptik meliputi warna, rasa, tekstur dan kesukaan. Pengujian parameter terlebih dahulu di uji normalitasnya dengan menggunakan uji Shapiro-Wilk. Apabila sebaran datanya normal dianalisis dengan ANOVA pada taraf 5\%, apabila terdapat pengaruh dilanjutkan dengan uji Wilayah Ganda Duncan. Kadar benzo (a) pirene dan kadar benzo (a) antarcena di uji secara deskriptif dan pengujian sifat organoleptik (warna, rasa, tekstur dan tingkat kesukaan) menggunakan uji Non Parametrik Kruskal - Walis dan dilanjutkan, uji beda nyata Man Whitney. Hasil penelitian ini menunjukkan bahwa konsentrasi asap cair berbeda dapat memberikan pengaruh yang nyata $(\mathrm{P}<0,05)$ terhadap kadar protein, kadar fenol dan organoleptik. Konsentrasi asap cair tertinggi dapat meningkatkan kadar fenol, organoleptic tetapi dapat menurunkan kadar protein. Sedangkan kadar benzo (a) pirene pada
\end{abstract}


semua perlakuan adalah $<0,51 \mathrm{mg} / \mathrm{kg}$ dan kadar benzo (a) antracena pada semua perlakuan adalah $<9,08$ dan secara kesehatan pemanfaatan asap cair sampai pada 9\% masih aman untuk dikonsumsi.

Kata kunci: Daging., konsentrasi asap cair., dendeng., Kimiawi dendeng, Organoleptik.

Y. Tamu Ina, I. Patu Sirappa. 2021. Pemanfaatan cair tempurung kelapa dan pengaruhnya terhadap organoleptikk dan kimiawi daging sapi. Jurnal Peternakan Nusantara 7(1): 41-50.

\section{PENDAHULUAN}

Penggunaan asap cair mulai dikembangkan pada akhir tahun 1980 untuk menggantikan proses pengasapan tradisional (Pszczola,1995). Perkembangan produksi dan penggunaan asap cair pada pangan pesat, hal ini dapat dilihat banyaknya penelitian produksi asap cair dari berbagai macam bahan baku termasuk penggunaan tempurung kelapa (Wahab, 2009), berbagai jenis kayu (Tranggono et al., 1997 ; Stumpe-Viksana et al., 2008 ). Asap cair merupakan cairan hasil kondensasi dari proses pirolosis kayu yang dapat digunakan sebagai antioksidan alami pada proses pengolahan bahan pangan termasuk daging, ikan dan hasil olahan lainnya (Apituley et al.,2013; Arizona et al., 2011). Sifat antioksidatif dari asap cair ini disebabkan karena adanya senyawa-senyawa fenolik seperti guaiakol dan syringol (Maga et al., 1987).

Pengolahan daging sapi menjadi produk asap merupakan salah satu pilihan yang dapat dilakukan untuk mengurangi kendala yang ada serta upaya diversifikasi produk olahan pangan asal daging sapi (Jahidin, 2016). Thohari (2013) menyatakan bahwa pengasapan adalah proses pengawetan daging menggunakan kombinasi panas dan bahan kimia yang dihasilkan dari pembakaran kayu-kayu keras. Tempurung kelapa adalah salah satu bahan baku yang sangat potensial untuk dijadikan asap cair. Husseinsyah dan Mostapha (2011) menyatakan bahwa, dalam tempurung kelapa mengandung pentosa sebanyak $27,7 \%$, selulosa $26,6 \%$, lignin 29,4\%. Fitrahuddin (2018) menyatakan bahwa Secara umum, asap cair tempurung kelapa dapat dimanfaatkan sebagai bahan pengawet makanan alternatif yang aman untuk dikonsumsi, serta memberikan karakteristik sensori berupa warna, aroma, serta rasa yang khas pada produk pangan. Kandungan senyawa fenol dalam asap cair berfungsi sebagai antioksidan yang mampu memperpanjang masa simpan suatu bahan makanan dan mampu mencegah tumbuhnya suatu mikroba dalam bahan makanan tersebut.
Metode pengasapan daging asap di masyarakat masih dilakukan secara beragam disesuaikan dengan selera pembuatnya, kondisi ini tentu dapat berdampak pada kualitas produk yang ada, sehingga dikhawatirkan produk yang dihasilkan dapat mengalami penurunan kualitas secara fisik dan kimia (Jahidin, 2016). Berdasarkan uraian tersebut diatas, maka dalam upaya meningkatkan kualitas organolpetik dendeng, penelitian ini bertujuan untuk mendapatkan konsentasi asap cair terbaik sebagai bahan pembuat dendeng sapi dengan menganalisis kadar protein, kadar fenol, kadar benzo (a) antracena, kadar benzo (a) pirene dan Organoleptik (Warna, rasa, tekstur dan kesukaan ) pada dendeng sapi. Konsentrasi asap yang terbaik dapat memberikan informasi bagi indutri pembuatan dendeng dalam meningkatkan kualitas gizi dan kesehatan pada dendeng.

\section{MATERI DAN METODE}

\section{Materi}

Bahan yang digunakan dalam penelitian ini adalah daging segar sapi jantan peranakan Ongole yaitu daging diambil pada bagian bottom round yang di peroleh dari rumah potong hewan (RPH) Penggaron Kota Semarang, Madu diperoleh dari Pulau Timor, Provinsi Nusa Tenggara Timur, Asap cair tempurung kelapa diperoleh dari hasil pengolahan sendiri oleh peneliti di Laboratorium Terpadu Universitas Diponegoro. Alat yang digunakan dalam penelitian adalah mesin pengolahan asap cair (rancangan sendiri oleh peneliti) Labu takar 25 ml untuk menampung asap cair olahan, Corong dan ketas saring untuk menyaring asap cair sebelum di aplikasikan kedaging pelakuan. Daging diiris dengan menggunakan mesin pengiris daging "Wirastar MGD G3", dan mengupas bumbu menggunakan pisau, selanjutnya daging perlakuan Di tempatkan pada beaker glass $250 \mathrm{ml}$ dan diberi label menggunakan kertas label dan gunakan Pipet tetes $10 \mathrm{ml}$ untuk mengambil cairan asap cair 
dan diteteskan pada daging perlakuan menggunakan batang pengaduk agar daging tercampur merata dengan bumbu dan asap cair, daging perlakuan ditutup dengan cling wrap, lalu direndam selama 30 menit, daging ditirisakan selam 30 menit, wadah daging dialasi dengan alumunium foil dan diovenkan selama 4 jam. Daging yang telah di asapi ditaruh pada pada zipperbag dan untuk dilanjutkan pengujian variable. Proses pengerjaan di laboratorium selalu menggunakan masker, dan sarung tangan untuk mencegah penularan penyakit dan setiap kegiatan di dokumentasi menggunakan kamera dan alat tulis lainnya.

\section{Metode Penelitian}

Penelitian dilaksanakan selama 3 bulan yaitu pada bulan agustus 2018 sampai dengan Oktober 2018. Penelitian ini menggunakan Rancangan Acak Lengkap yaitu perendaman daging dengan konsentrasi asap cair yang berbeda. Penggunaan asap cair tempurung kelapa mempunyai 3 taraf konsentrasi pengasapan yaitu $\mathrm{P} 1=3 \%$, P2=6\%, dan $\mathrm{P} 3=9 \%$. Kebutuhan untuk perendaman daging dengan menggunakan asap cair adalah 15 sampel.
Variabel yang diukur adalah kadar fenol, kadar protein, kadar benzo (a) pirene, kadar benzo (a) antracena, organoleptik meliputi warna, rasa, tekstur dan kesukaan.

\section{Prosedur Pengolahan dendeng}

Pembuatan dendeng didahului dengan menghilangkan lemak eksternal pada daging dan tahap selanjutnya daging di iris secara melintang dengan ketebalan $3 \mathrm{~mm}$. Potongan daging hasil irisan selanjutnya dibagi sesuai ulangan perlakuan, direndam di dalam larutan gula kelapa dan madu yaitu $7,5 \%+22,5 \%$ (Ina, et al, 2019) ; asap cair 3\%, 6\% dan 9\%. Selanjutnya dilakukan pengeringan dengan suhu $55^{\circ} \mathrm{C}$ dan dengan lama waktu masingmasing 4 jam. Daging yang sudah kering, diuji variabel.

\section{Analisis Variabel}

\section{Kadar Protein}

Penentuan kadar protein dihitung dengan penentuan total $\mathrm{N}$ bahan dengan metode semi mikro kjeldah ( Legowo et al, 2005).

Total $\mathrm{N}$ dapat dihitung dengan persamaan sebagai berikut:

$$
\% \mathrm{~N}=\frac{(\mathrm{ml} \mathrm{HCL}-\mathrm{ml} \text { blangko) } \mathrm{x} \text { Normalitas HCL x 14,008 x } 100}{\text { Mg sampel }}
$$

$\%$ Protein total $=\% \mathrm{~N} \times$ Faktor Konversi

\section{Kadar Total Fenol}

Penentuan kadar fenol secara kuantitatif dilakukan dengan spektrofotometri menggunakan metode Folin Ciocalteu ( Julkunen-Tiitto, 1985). Sampel ditimbang sebanyak 54,8 mg kemudian ditempatkan dalam labu ukur $10 \mathrm{ml}$ dan ditambahkan $250 \mu \mathrm{l}$ reagen folin ciocalteu. Setelah 1 menit, ditambahkan $750 \mu \mathrm{l}$ natrium carbonat 20\%. Selanjutnya ditambahkan aquades hingga batas $10 \mathrm{ml}$ dan diinkubasikan pada suhu $25^{\circ} \mathrm{C}$ selama 2 jam. Sampel dalam labu ukur dipindahkan ke dalam kuvet dan dibaca serapannya dengan spektrofotometri pada panjang gelombang 760 $\mathrm{nm}$. Pembuatan standar pembanding dilakukan dengan menggunakan gallic acid. Pembuatan standar ini dilakukan dengan menimbang 20,0 mg gallic acid dan kemudian dilakukan preparasi seperti di atas.

\section{Kadar Benzo (a) pirene dan Benzo} (a) antracena
Pengujian terhadap Kadar benzo (a) pirene dan kadar benzo (a) antracena menggunakan kromatografi gas Shimadzu tipe GC 2010. Tahapan pengujian yaitu daging dicincang dan di timbang sekitar $50 \mathrm{~g}$, dicampur dengan $30 \mathrm{~mL}$ $\mathrm{KOH} \mathrm{50 \% .} \mathrm{dimasukkan} \mathrm{di} \mathrm{waterbath} \mathrm{air} \mathrm{700c}$ selama 30 menit dengan sering digoyanggoyangkan. Campuran diekstaksi dengan $30 \mathrm{ml}$ CHCL2 dan ditampung. Ekstraksi lagi dengan 20 ml CHLC2 . Ekstrak jadikan satu, diuapkan sampai $5 \mathrm{ml}$ dengan rotary evaporator. Sep-Pak diaktifkan dengan metanol. Konsentrat dichloromethane dituangkan ke dalam catridge Sep-Pak florisil. $10 \mathrm{ml}$ alikuot metanol digunakan untuk eluet bahan kimia dan eluat itu dikumpulkan. Evoporasi sampai kering dengan N2. Encerkan dengan dichloromethan.

\section{Analisis Data}

Pengujian parameter terlebih dahulu di uji normalitasnya dengan menggunakan uji Shapiro-Wilk. Apabila sebaran datanya normal dianalisis dengan ANOVA pada taraf $5 \%$, apabila terdapat pengaruh dilanjutkan dengan uji 
Wilayah Ganda Duncan (Steel et al., 1997). Kadar benzo (a) pirene dan kadar benzo (a) antarcena di uji secara deskriptif dan pengujian sifat organoleptik (warna, rasa, tekstur dan tingkat kesukaan) menggunakan uji Non Parametrik Kruskal - Walis dan dilanjutkan, uji beda nyata Man Whitney (dimodifikasi dari Jannah, 2014). Model Statistik dari dari rancangan acak lengkap adalah:

Yijk $=\mu+\alpha i+\varepsilon i j$

Keterangan:
$\mathrm{I}=1,2,3$

$\mathrm{J}=1,2,3,4,5$

Yij $=$ Hasil pengamatan pengamatan perlakuan ke-i dan ulangan ke-j

$\mu=$ Nilai tengah umum hasil pengamatan

$\alpha \mathrm{i}=$ pengaruh perlakuan

zij $=$ Pengaruh galat percobaan akibat perlakuan ke-i dan ulangan ke-j

$\mathrm{i}=$ perlakuan $1,2,3$

$\mathrm{j} \quad=$ Ulangan $(1,2,3,4$, dan 5$)$

\section{HASIL DAN PEMBAHASAN}

\section{Total Fenol}

Berdasarkan hasil penelitian yang telah dilakukan, diperoleh data rerata fenol yang tersaji pada Tabel 1.

Tabel 1. Rerata Kadar Fenol Dendeng Sapi dengan Konsentrasi Asap Cair yang Berbeda

\begin{tabular}{|c|c|c|c|}
\hline \multicolumn{2}{|c|}{ Kadar Fenol } & \multicolumn{2}{|c|}{ Perlakuan asap cair (\%) } \\
\hline & 3 & 6 & 9 \\
\hline \multicolumn{4}{|c|}{ 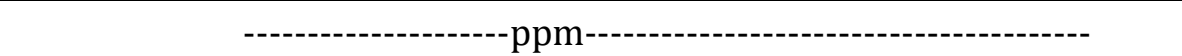 } \\
\hline $\mathrm{U} 1$ & 831,7152 & 1236,750 & 1893,127 \\
\hline $\mathrm{U} 2$ & 845,3467 & 1232,762 & 1879,794 \\
\hline U3 & 856,5489 & 1290,958 & 1863,794 \\
\hline $\mathrm{U} 4$ & 872,5413 & 1242,424 & 1818,802 \\
\hline U5 & 878,2812 & 1227,451 & 1818,633 \\
\hline Rerata & 856,8867 a & $1246,069^{b}$ & $1854,83^{\circ}$ \\
\hline
\end{tabular}

Keterangan: Superskrip, huruf kecil yang berbeda pada baris rerata menunjukkan perbedaan nyata

$(\mathrm{P}<0,05$

Hasil analisis ragam menunjukkan, bahwa pemberian asap cair dengan konsentrasi berbeda pada semua perlakuan berpengaruh nyata $(\mathrm{P}<0,05)$ dalam meningkatkan kadar fenol dendeng sapi dengan rerata kadar fenol tertinggi 1854 (pengasapan 9\%), 1246,069 (pengasapan 6\%) dan terendah 856,8867 (pengasapan 3\%). Hasil penelitian (Tabel 1) menunjukkan, bahwa semakin tinggi konsentrasi asap cair yang diberikan pada daging menghasilkan kadar fenol yang semakin tinggi. Penelitian tersebut tidak sejalan dengan penelitian Thohari et al. (2017) yang menunjukkan, bahwa daging sapi ongole yang mendapatkan perlakuan asap cair dapat mengahasilkan kadar fenol yaitu 4,023-5,093. Hasil penelitian menunjukkan adanya peningkatan kadar fenol diduga terjadi dipolimerisasi lignin yang terkandung dalam tempurung kelapa yang mengakibatkan terbentuknya fenol bebas. Fenol dapat bereaksi dengan gugus amino bebas, gugus karbonil dan ikatan rangkap melalui adisi, bereaksi dengan karbonil dan nitrit dalam produk yang diasap. Peningkatan kadar fenol diduga pula dipengaruhi oleh adanya air lepas akibat denaturasi protein. Denaturasi protein akan menurunkan kemampuan menahan air intramuskuler. Air yang lepas akan bereaksi dengan komponen turunan benzen membentuk senyawa fenol.

Analisa kadar fenol dilakukan untuk mengetahui jumlah fenol yang terkandung dalam produk, apakah termasuk dalam batas normal atau tidak, karena jika tidak berada dalam batas normal akan menghasilkan produk yang kurang baik (Hutomo et al.,2015). Fenol yang memenuhi batas normal dapat memperpanjang daya awet produk. Berdasarkan kebutuhan kadar fenol untuk dikonsumsi dalam hasil penelitian dengan konsentrasi asap 3\% adalah hasil terbaik. Hal ini diperkuat oleh Riyadi et al. (2009) menunjukkan, bahwa batas maksimal kadar fenol yang diperbolehkan dalam bahan makanan (200-1000ppm) sehingga aman untuk 
dikonsumsi serta dapat diterima konsumen dari karakter sensoris, fisik dan kimia.
Berdasarkan hasil penelitian yang telah dilakukan, diperoleh data rerata kadar protein yang tersaji pada Tabel 2 .

\section{Kadar Protein}

Tabel 2. Rerata Kadar Protein Dendeng Sapi dengan Konsentrasi Asap Cair yang Berbeda

\begin{tabular}{cccc}
\hline \multirow{2}{*}{ Ulangan } & \multicolumn{3}{c}{ Perlakuan asap cair (\%) } \\
\cline { 2 - 4 } & & 6 & 9 \\
\hline & 39,90 & 38,36 & 33,13 \\
2 & 39,10 & 36,61 & 36,65 \\
3 & 35,69 & 38,48 & 36,75 \\
4 & 38,90 & 33,16 & 33,57 \\
5 & 37,66 & 37,34 & 32,31 \\
\hline Rerata & $38,25^{\text {a }}$ & 36,79 ab & $34,48^{\mathrm{b}}$ \\
\hline \hline
\end{tabular}

Keterangan: Superskrip, huruf kecil yang berbeda pada baris rerata menunjukkan perbedaan nyata $(\mathrm{P}<0,05)$

Hasil analisis ragam menunjukkan, bahwa perlakuan konsentrasi asap cair yang berbeda terdapat adanya pengaruh nyata $(\mathrm{P}<0.05)$ terhadap kadar protein dendeng sapi. Uji Lanjut Wilayah Ganda Duncan menunjukkan, bahwa pemberian asap cair dengan konsentrasi berbeda pada perlakuan 3\% dan 9\% menunjukkan, adanya perbedaan nyata tetapi cenderung tidak berbeda nyata pada perlakuan asap $6 \%$.

Hasil penelitian (Tabel 2) menunjukkan, bahwa pemberian konsentrasi asap cair 3\% dapat meningkatkan kadar protein menjadi $38,25 \%$ tetapi konsentrasi asap $9 \%$ mengakibatkan penurunan kadar protein (34,48\%). Kadar protein cenderung menurun diduga karena asap yang terendam dalam daging menyebabkan lisis pada komponenkomponen terlarut dalam sel. Semakin besar konsentrasi perendaman asap cair, semakin meningkat jumlah komponen terlarut termasuk protein sel yang mengalami lisis. Penelitian ini berbeda dengan hasil penelitian Dheko et al. (2017) yang menunjukkan, bahwa daging se'i sapi bali yang diasapi dengan asap cair tempurung kelapa 2\% sampai dengan 10\% menghasilkan kadar protein yang semakin meningkat yaitu 49,49-59,61\%. Selanjutnya penelitian Ratna et al. (2017) menunjukkan, bahwa pemanfaatan asap cair 2\%-6\% menghasilkan kadar protein 31,74 sampai dengan 33,30\%. Berdasarkan kebutuhan kadar protein, hasil penelitian ini menunjukkan kadar protein perlakuan asap 3\% dan 9\% dengan rerata $34,48 \%-38,25 \%$ adalah terbaik karena sangat dekat persyaratan Badan Standardisasi Nasional (1992) dalam SNI 01-2908-1992 untuk dendeng kualitas I adalah 30\%.

\section{Kadar Benzo (a) Pirene dan Benzo (a) Antaracena}

Hasil perlakuan pengasapan berbeda diperoleh data kadar benzo (a) pirene dan benzo (a) antarcena yang tersaji pada tabel 3. Kadar benzo (a) pirene dan benzo (a) antarcena dinilai berbahaya karena bersifat karsinogenik.. Senyawa ini dapat terserap ke dalam tubuh. Hasil penelitian (Tabel 3) menunjukkan, bahwa perlakuan konsentrasi asap cair yang berbeda berpengaruh terhadap kadar benzo (a) pirene dan benzo (a) antarcena. Komponen benzo(a Jpiren dan benzo (a) antarcena merupakan jenis PAH yang memiliki tingkat karsinogenik tinggi dan telah umum digunakan sebagai indikator adanya kelompok senyaawa PAH (Benford et al., 2010). 
Tabel 3. Hasil Analisis Senyawa PAH Dendeng Asap dengan konsentrasi Asap Cair Berbeda

\begin{tabular}{cccc}
\hline & \multicolumn{4}{c}{ Konsentrasi Asap (\%) } \\
\hline Parameter uji & 3 & 6 & 9 \\
& $---1-0-1$ & $<9,08$ \\
Benzo@antacene & $<9,08$ & $<9,08$ & $<0,51$ \\
Benzo(a)pyrene & $<0,51$ & $<0,51$ & \\
\hline
\end{tabular}

Referensi: Aloysius (2017)

Tabel 3 menunjukkan bahwa pengasapan 3\%-9\% kadar benzo(a) piren yaitu $<0,51 \mathrm{mg} / \mathrm{kg}$, benzo (a) antarcena $<9,08$, hasil penelitian ini tidak melebihi batas maksimal yang ditetapkan oleh WHO (1987) yang menetapkan konsentrasi benzo (a) piren dan benzo (a) antaracena maksimum di dalam makanan adalah $10 \mu \mathrm{g} / \mathrm{kg}$. Kadar benzo(a)piren dan benzo (a) antaracena yang dihasilkan berbeda dengan Darmadji (1997) menunjukkan, bahwa kadar benzo(a) piren dan benzo (a) antarcena sate daging kambing sebesar 1,76 $\mathrm{mg} / \mathrm{kg}$ yang dibakar dengan arang, sedangkan yang dibakar dengan kompor gas sebesar 0,78 $\mathrm{mg} / \mathrm{kg}$. Terzi et al. (2008) mendeteksi konsentrasi benzo(a)piren pada sampel daging yang dimasak dengan bara api sebesar 24,2 $\mu \mathrm{g} / \mathrm{kg}$ dan $5,7 \mu \mathrm{g} / \mathrm{kg}$ daging dimasak dengan gas. Berdasarkan benzo (a) piren dan benzo (a) antaracena, hasil penelitian ini menunjukkan bahwa konsentrasi asap cair sampai dengan 9\% memenuhi batas keamanan untuk dikonsumsi.

\section{EValuasi Organoleptik (Warna, Rasa, Tekstur dan Kesukaan) \\ Warna}

Hasil uji organoleptik dari 25 panelis dihasilkan warna tertinggi coklat pada konsentrasi asap cair 6\%-9\% $\quad(3,0 \pm 0,28$ $3,8 \pm 0,50)$ dan terendah $3 \%(2,4 \pm 0,64)$ dengan kriteria agak coklat. Hasil analisis statistik dengan Uji Kruskal-Wallis (Tabel 4) menunjukkan, bahwa perendaman daging dengan bervariasi konsentrasi asap cair berbeda berpengaruh nyata $(\mathrm{P}<0,05)$ terhadap intensitas warna. Hal ini disebabkan adanya proses pemanasan sehingga reaksi maillard dapat berlangsung. Reaksi maillard adalah reaksi antara protein dengan gula pereduksi (Muchtadi et al., 1993). Kusnandar (2010) menyatakan, bahwa reaksi maillard menghasilkan pigmen melanoidin yang bertanggung jawab pada pembentukan warna coklat dan reaksi karamelisasi menghasilkan warna coklat melalui reaksi kimia yang terjadi pada gula sederhana karena adanya proses pemanasan. Disisi lain Moeljanto (1998) menyatakan, bahwa warna dihasilkan karena adanya reaksi kimia antara fenol dan 02 serta antara protein dan karbonil pada bahan yang dipanggang. Dengan demikian semakin tinggi 02 kadar fenol dan karbonil dalam asap, maka warna daging akan semakin kuning keemasan atau kecoklatan. Warna yang terjadi pada produk asapan merupakan hasil reaksi non-enzimatik, melalui reaksi kondensasi antara karbonil dan dikarbonil dalam asap dengan asam-asam amino protein dan asam amino bebas dalam produk pangan.

\section{Rasa}

Hasil analisis non parametrik Kruskali-Wallis terhadap dendeng asap menunjukkan adanya perbedaan rasa antar konsentrasi asap cair. Hal ini karena proses pengasapan sampai 9\% menimbulkan perbedaan rasa asap yang nyata. Rata-rata hasil analisis rasa dendeng asap matang dapat dilihat pada Tabel 4. Skor rasa daging asap matang pada semua perlakuan adalah2.28 $\pm 0.67-2.90 \pm 20.27$ (agak berasa asap). Evaluasi rasa sangat bergantung pada penel cita rasa. Rasa daging matang banyak ditemukan oleh prekursor yang larut dalam air dan lemak serta pembebasan substansi atsiri (volatil) yang terdapat dalam daging (Soeparno, 2009). Rasa dendeng asap melibatkan senyawa volatil asap cair yang terpenetrasi ke dalam daging dan senyawa baru yang terbentuk selama proses pemanasan. Senyawa tersebut diprediksi merupakan produksi reaksi maillard dan oksidasi yang diinduksi oleh panas. 


\section{Tekstur}

Tabel 4. Nilai Rata-rata Penilaian Organoleptik Dendeng Asap Dengan Berbagai Level Konsentrasi Asap Cair.

\begin{tabular}{|c|c|c|c|c|}
\hline & \multicolumn{4}{|l|}{ Variabel } \\
\hline Perlakuan Asap cair (\%) & ---.-. & -1.-.- & kor)-----. & -------------. \\
\hline Perlakuan & Warna & Rasa & Tekstur & Kesukaan \\
\hline $3 \%$ & $2.4 \pm 0.64^{a}$ & $2.28 \pm 0.67^{a}$ & $1.68 \pm 0.69^{a}$ & $1.36 \pm 0.63^{\mathrm{a}}$ \\
\hline $6 \%$ & $3.0 \pm 0.28^{\mathrm{b}}$ & $2.88 \pm 0.72^{b}$ & $1.96 \pm 0.45^{\mathrm{a}}$ & $2.20 \pm 0.40^{\mathrm{b}}$ \\
\hline $9 \%$ & $3.8 \pm 0.50^{c}$ & $2.9 \pm 20.27^{b}$ & $2.84 \pm 0.74^{b}$ & $3.20 \pm 10^{c}$ \\
\hline
\end{tabular}

Tabel 4 menunjukkan, bahwa hasil uji tekstur pada perlakuan asap cair $9 \%$ adalah yang tertinggi dengan skor nilai $(2.84 \pm 0.74)$ terlihat bahwa panelis memberikan penilaian dengan kriteria (agak empuk) diduga karena senyawa volatil dalam asap dapat berpengaruh terhadap keempukkan dendeng, sehingga memudahkan untuk digigit atau dikunyah, perlakuan terendah adalah konsentrasi asap 3\% dan 6\% (1.68 \pm 0.69 $1.96 \pm 0.45)$ terlihat panelis memberikan penilaian kriteria tidak empuk. Hasil analisis non parametrik Kruskall- Wallis menunjukkan bahwa uji tekstur dendeng asap matang yang menggunakan konsentrasi asap cair yang bervariasi berpengaruh nyata nyata $(\mathrm{P}<0,05)$ terhadap tekstur dendeng asap. Hal ini diduga konsentrasi pengasapan sampai dengan 9\% relatif berpengaruh terhadap keempukkan, karena komponen bioktif yang terdapat didalamnya dapat menghidrolisis ikatan-ikatan peptida pada protein dendeng sapi. Disisi lain

\section{Kesukaan}

Berdasarkan hasil penelitian yang telah dilakukan, diperoleh data rerata skor penilaian organoleptik yang tersaji pada Tabel 4. Hasil uji kruskal wallis menunjukkan, bahwa pemberian

Tabel 1 menunjukkan, bahwa kesukaan panelis terhadap keseluruhan produk dengan penilaian yang terendah adalah pada konsentrasi asap 3\% (1.36 \pm 0.63$)$ dengan kriteria tidak suka, konsentrasi asap 6\% panelis memberikan skor penilaian $(2.20 \pm 0.40)$ dengan kriteria kurang suka dan penilaian panelis yang tertinggi adalah perlakuan pengasapan $6 \%$ dengan skor nilai $(3.20 \pm 10)$ terlihat bahwa panelis memberikan penilaian dengan kriteria suka. Hal ini diduga bahwa asap cair memberikan sensasi baru dalam dendeng sapi, karena kandungan senyawa aromatik yang terkandung di dalamnya. Dendeng umumnya mempunyai rasa enak, karena ditambahkan adanya kemungkinan dipengaruhi oleh kadar air yang semakin sedikit sehingga tekstur mengkerut dan sedikit kasar. Permukaan daging yang dikeringkan akan mengeras karena daging kehilangan kandungan air selama pemanasan (Soeparno, 2009). Smith (2001) menyatakan, bahwa sifat fisik daging, seperti warna, tekstur, kekerasan dan keempukan daging dipengaruhi oleh daya ikat air, kadar air merupakan kemampuan matriks protein untuk menahan air atau menyerap air yang ditambahkan karena pengaruh luar seperti pemasakan. Toldra (2011) menyatakan, bahwa tekstur suatu produk yang dihasilkan tergantung pada banyaknya protein miofibrillar yang terdegradasi, tingkat pengeringan, tingkat degadrasi jaringan penghubung dalam daging dan kandungan lemak intramuskular dalam daging.

asap cair dengan konsentrasi berbeda pada semua perlakuan berpengaruh nyata $(\mathrm{P}<0,05)$ dalam meningkatkan kesukaan panelis terhadap dendeng asap.

bumbu-bumbu berupa garam, gula, ketumbar, asam dan bawang putih, serta mempunyai warna coklat kehitaman yang disebabkan oleh pigmen melanoidin yang dihasilkan oleh reaksi pencoklatan non enzimatis, kemungkinan warna dapat pula disebabkan oleh adanya proses karamelisasi selama proses pembuatan dendeng tersebut. Rahayu (2012) menyatakan bahwa panelis cenderung lebih menyukai dendeng sapi dengan penambahan asap cair. Berdasarkan penilaian Organoleptik hasil penelitian ini perlakuan dengan kosentrasi asap 6\% adalah terbaik karena kesukaan (mencakup warna, rasa dan tekstur) terhadap produk dendeng masih diterima oleh panelis. 


\section{KESIMPULAN DAN IMPLIKASI}

\section{Kesimpulan}

Konsentrasi asap cair tertinggi dapat meningkatkan kadar fenol, organoleptic (meliputi warna, rasa, tekstur dan kesukaan), tetapi dapat menurunkan kadar protein. Sedangkan kadar benzo (a) pirene pada semua perlakuan adalah $<0,51 \mathrm{mg} / \mathrm{kg}$ dan kadar benzo (a) antracena pada semua perlakuan adalah $<9,08$ dan secara kesehatan pemanfaatan asap cair sampai pada $9 \%$ masih aman untuk dikonsumsi.

\section{Implikasi}

Penelitian inin diharapkan dapat memberikan informasi baru dalam bidang pengolahan hasil ternak tentang pemanfaatan asap cair tempurung kelapa sebagai pengawet alami untuk produk daging. Peneltian ini juga dapat diterapkan oleh masyarakat dan industry pengolahan daging.

\section{Ucapan Terima Kasih}

Penulis mengucapkan terima kasih kepada program studi peternakan, fakultas sains dan teknologi, Universitas Kristen Wira Wacana Sumba (Unkriswina Sumba) yang telah memberikan dana penelitian kepada penulis hingga tahap penulisan artikel ini.

\section{DAFTAR PUSTAKA}

Apituley, D.A.N., dan P. Darmadji. 2013. Daya hambat asap cair kulit batang sagu terhadap kerusakan oksidatif lemak ikan tuna (Thunnus Sp) Asap. Agritech 33(2).

Arizona R., Suryanto, E., Erwanto, Y. 2011. Pengaruh konsentrasi asap cair tempurung kenari dan lama penyimpanan terhadap kualitas kimia dan fisik daging. Jurnal Buletin Peternakan 35(1):5056. DOI.10.21059/bulletin peternak.v35i1.590.

Benford, D., M. Dinovi and R. W. Setzer. 2010. Application of the margin-of-exposure (MoE) aprroach to substances in food tht genotoxic and carcinogenik e,g: benzo (a)pyrene and polycyclic. Toxicol. 48:42-48.

Dheko, L.K. D. Darmakusuma dan P.R. Kale. 2017. Aplikasi Asap Cair Tempurung kelapa rendah benzo ( a) pyrene untuk meningkatkan kualitas se'i sapi bali. Sains Peternakan. 15(1):8-15.

Darmadji, P. 1997. Investigasi senyawa karsinogen benzopyrene dalam sate. Laporan Penelitian. Jurusan Teknologi Hasil Pertanian, Fakultas Pertanian, Universitas Gadjah Mada. Yogyakarta.

Fitrahuddin Assidiqi, Tina Dewi Rosahdil, Baiq Vera El Vierai. 2018. Pemanfaatan Asap Cair Tempurung Kelapa dalam Pengawetan Daging Sapi. Al-kimiya 5 (1): 34-41

Husseinsyah S and M Mosthapa, "The Effect of Filter Content On Properties of Coconut Shell Filled Polyester Composite," vol. 6, pp. 87-97, 2011

Hutomo, H.D, F. Swastawati dan L. Rianingsih. 2015. Pengaruh konsentrasi asap cair terhadap kualitas dan kadar kolesterol belut (Monopterus albus) Asap. Jurnal pengolahan dan Bioteknologi Hasil Perikanan. 4(1):7-14.

Ina , Y. T., Widiyanto, Bintoro V.P. 2019. Sifat Fisikokimia Dendeng Sapi yang Direndam dalam Gula-Kelapa dan Madu . Jurnal Aplikasi Teknologi Pangan 8 doi.org/10.17728/jatp.3760

Jahidin Jaya Putra. Kualitas Fisik Daging Asap dari Daging yang Berbeda Pada Pengasapan Tradisional. 2016. Jurnal Ilmu-IImu Peternakan XIX (1) 27-34

Kusnandar, F . 2010. Kimia Pangan Komponen Makro. Dian Rakyat. Jakarta.

Moeljanto, R. 1998. Pengolahan Ikan untuk Indonesia. Nelpan. Jakarta.

Maga, J.A. 1987. Smoke in food processing. CRC. Press. Incorporation. Boca Raton, Florida.

Muchtadi, D., N. Palupi, Dan M. Astawan. 1993. Metabolisme Zat Gizi Sumber dan Kebutuhan bagi Tubuh Manusia. Pustaka Sinar Harapan Jakarta.

Moeljanto, R. 1998. Pengolahan Ikan untuk Indonesia. Nelpan. Jakarta.

Pszczola, D.E. 1995. Tour highlights production and uses of smoke base flavors. Food Technol. 49:70-74

Rahayu, S., dan V.P. Bintoro. 2012. Pengaruh pemberian asap cair dan metode pengemasan terhadap kualitas dan tingkat kesukaan dendeng sapi selama penyimpanan. JATP. 1(4).

Ratna, S.S., S. Agustini, A. Wijaya, dan R. Pambayun. 2017. Profil mutu ikan lele (Clarias gariepinus) asap yang diberi 
perlakuan gambir (Uncaria Gambir Roxb). JDPI. 28(2):101-111.

Riyadi, N.H., W. Atmaka. 2009. Diversifikasi dan karakterisasi citarasa bakso ikan tenggiri (Scomberomorus commersonii) dengan penambahan asap cair tempurung kelapa. Jurusan Ilmu dan Teknologi Pangan, Fakultas Peternakan. Universitas Sebelas Maret. Surakarta.

Soeparno. 2009. Ilmu dan Teknologi Daging. Cetakan kelima. Gadjah Mada University Press, Yogyakarta.

Steel, R.G.D., J.H. Torrie and D.A. Dickey. 1997. Principles and procedures of statistik a biomedical approach, 3rd Edition. McGraw Hill, Inc, Singapore.

Smith, D. M. 2001. Fuctional properties of muscle proteins in processed poultry products. In: Poultry Meat Processing. A. R. Sams (ed). CRC Press. Washington.

Stumpe-Viksana, I., V. Bartkevics. A. Kukare, and A. Marozovs. 2008. Polycyclic aromatic hydrocarbons in meat smoked with differne type of wood. J. Food Sci. 110: 794-797.

Terzi, G., T. H. Celik anad C.Nisbet. 2008. Determination of benzo (a)pyrene in Turkish doner kebab sample cooked with charcoal or gas fire. IRISH J AGR. FOOD RES. 47: 187-193.
Thohari I, Eny SW, Agustina WK, Mohamad A. 2013. Kualitas Daging Asap yang Diawetkan dengan Metode Pengawetan yang Berbeda. Jurnal Ilmu dan Teknologi Hasil Ternak. Vol.8 (2): 23-26.

Toldra F, Milagro R. 2011. Innovation for Healthier Processed Meats. Trends in Food Science dan Technology. 22 (9): 517522.https://doi.org/10.1016/j.tifs.2011.08.0 07

Wahab , S. 2009. Pengaruh Komposisi Bahan Baku dan Suhu Pirolisis Terhadap Senyawa Penyusun Asap Cair dari Tempurung Biji Pala dan Tempurung Kelapa. [Tesis]. Program Magister Sistem Teknik. Konsentrasi Teknik Pengelolaan dan Pemanfaatan Sampah/Limbah Perkotaan. Jurusan Ilmu Teknik. Fakultas Teknik. Sekolah Pascasarjana. Universitas Gadjah Mada, Yogyakarta.

Tranggono, Suhardi, B. Setiadji, Supranto, P. Darmadji, dan Sudarmanto. 1996. Identifikasi asap cair dari berbagai jenis kayu dan tempurung kelapa. JITP 1 ( 2 ): 15-24.

Thohari I., E.S. Widyastuti, A.W. Kunharjanty dan Mohamad. 2017. Kualitas daging asap yang diawetkan dengan metode pengasapan yang berbeda. JITEK

8(2):23-26. 
